\title{
Tulane
}

Tulane Economics Working Paper Series

\section{Coping with Rising Food Prices: Policy Dilemmas in the Developing World}

\author{
Nora Lustig \\ Department of Economics \\ 206 Tilton Hall \\ Tulane University \\ New Orleans, LA 70118 \\ nlustig@gwu.edu \\ Working Paper 0907 \\ May 2009
}

\begin{abstract}
Rising food prices cause considerable policy dilemmas for developing country governments. Letting domestic prices adjust to reflect the full change in international prices generates inflationary pressures and causes severe hardship for poor households lacking access to social safety nets. Alternatively, governments can use food subsidies or export restrictions to stabilize domestic prices, yet this exacerbates global food price increases and undermines a rules-based trading system. The recent episode shows that many countries chose to shift the burden of adjustment back to international markets. Corn and oilseeds use for biofuels' production will result in a recurrence of such episodes in the foreseeable future.
\end{abstract}

Keywords: food prices, inflation, poverty, Africa, Asia, Latin America and the Caribbean JEL: E31, I38, Q18, O24 
Coping with Rising Food Prices: Policy Dilemmas in the Developing World ${ }^{1}$

\author{
Nora Lustig \\ Shapiro Visiting Professor of International Affairs \\ Elliott School of International Affairs \\ George Washington University \\ and \\ Visiting Fellow \\ Center for Global Development
}

March 11, 2009

\begin{abstract}
Rising food prices cause considerable policy dilemmas for developing country governments. Letting domestic prices adjust to reflect the full change in international prices generates inflationary pressures and causes severe hardship for poor households lacking access to social safety nets. Alternatively, governments can use food subsidies or export restrictions to stabilize domestic prices, yet this exacerbates global food price increases and undermines a rules-based trading system. The recent episode shows that many countries chose to shift the burden of adjustment back to international markets. Corn and oilseeds use for biofuels' production will result in a recurrence of such episodes in the foreseeable future.
\end{abstract}

Key Words: Food Prices, Inflation, Poverty, Africa, Asia, Latin America and the Caribbean.

\footnotetext{
${ }^{1}$ The author is very grateful to Nancy Birdsall, Alain de Janvry, Kim Elliott, Alain Ize, Steve Kamin, Will Martin, Darryl McLeod and Peter Timmer for their comments on an earlier version. Needless to say, they do not bear any responsibility for any omissions, errors or mistakes. The author is also very grateful to Maria Davalos and Amanda Lintelman for their excellent research assistantship.
} 
World prices of food commodities increased 130 percent from January 2002 to June 2008 (Figure 1). Individual agricultural commodities show even more pronounced increases: corn, wheat, rice and soybeans rose by 190, 162, 318 and 246 percent, respectively. Since July 2008, food commodities prices began to fall. While this decline comes as a relief, prices are likely to stay high in the foreseeable future. Although domestic food prices have not risen as rapidly as international prices, in many poor countries food inflation increased quite sharply. For example, in Sub-Saharan Africa food inflation increased to more than 17.7 percent and reached 80 percent in Ethiopia. ${ }^{1}$ In Bolivia, Azerbaijan, Bulgaria and Costa Rica it increased to 20 percent and it reached 30 percent in the Kyrgyz Republic and Sri Lanka for a similar period. ${ }^{2}$

Rising food prices are a cause of major concern because they bring significant and immediate setbacks for poverty reduction, social stability, inflation and a rules-based trading system. When confronted with rising food prices, governments in developing countries face difficult policy dilemmas, especially when it comes to the prices of basic staples such as rice and corn. One option is to let domestic prices adjust to reflect the full change in international prices, shifting the burden of adjustment to their own citizens. Since food represents a relatively large share of developing countries' consumption baskets, this results in inflationary pressures and hurts the living standards of poor net consumers. $^{3}$ Countries with large international reserves could mitigate these effects by appreciating their currency. However, an exchange rate appreciation hurts the tradable sector $^{4}$ and may cause macroeconomic imbalances down the road. Governments could also use safety nets to protect the poor from rising prices. However, in many developing countries safety nets are lacking or inadequate. In addition, safety nets for the poor do not help contain inflationary pressures or protect households in the middle of the income distribution who are not poor enough to be included in the safety net system but are also hurt by rising food prices.

Alternatively, governments can use food subsidies or export restrictions to stabilize domestic prices, shifting the burden of adjustment back to international markets. The former measures exacerbate global food price fluctuations and thus are a "beggar-thyneighbor" policy response and, depending on the measure, undermine a rules-based trading system. While administrative measures have costs for the countries that implement them, they may be smaller than the alternative, particularly when prices are subject to 
large fluctuations within short time periods. Without a multilateral solution to food price volatility in international markets, it is not surprising that developing countries pursue what is perceived as best for them even if the rest of the world is made worse off.

Using the recent period of rising food commodities prices, this paper examines the policy dilemmas and challenges faced by developing country governments when confronted with volatile food prices. It begins with a summary of the main drivers of the acceleration in food price increases especially since 2004. The paper goes on to show that rising food prices caused significant inflationary pressures and increased poverty in many countries throughout the developing world. Section three discusses a sample of the complex policy dilemmas and challenges governments in developing countries face. Section four presents concluding remarks.

\section{The Causes of Rising Food Commodities Prices}

Table 1 presents a summary of the factors that have been mentioned as potentially significant in explaining the phenomenon of rising food prices. Not all of them have survived a closer scrutiny, though. A review of the literature suggests that-in addition to temporary idiosyncratic factors such as bad weather and higher costs linked to energy prices - a key driver of the acceleration in food commodities price increases since 2004 was the increase in demand for industrial use due to the surge in the production of biofuels in advanced countries. From mid-2007 to mid-2008, price increases accelerated even further, but have fallen since. While the market dynamics during this period are still not well understood, a combination of macroeconomic factors such as the depreciation of the dollar and lower interest rates in the United States, as well as export-restricting policies on the part of developing countries seem to have played an important role. ${ }^{5}$

By and large, the performance of agriculture over the past twenty five years has been viewed as a success story. Between 1980 and 2004, output grew at an average of two percent per year and prices fell at an average of 1.6 percent. ${ }^{6}$ Due to supply-side constraints arising from land and water scarcity and slow technical progress, this success story was about to conclude. Analysts at IFPRI (International Food Policy Research Institute) and the FAO predicted that food prices would rise by 0.26 percent per year from around 2000 until 2030 and 0.82 percent per year from 2030 to $2050{ }^{7}$ However, in the first years of this decade, the increase was much larger. From January 2002 to July 2008, the price index of internationally traded food commodities prices increased by about 20 
percent per year or 100 times more than the predictions of the "business as usual" scenarios (!).

A closer analysis of what happened to demand and supply in the markets for grains and oilseeds from 2000 onwards may help explain this unexpected hike in prices. Table 2 summarizes the trends in harvested area, yields, food consumption, industrial use and stocks-to-use ratios for corn, rice, wheat and oilseeds. Evidence suggests that there was a steady decline in harvested area of wheat in particular at the beginning of the decade, a likely result of low prices in the past. ${ }^{8}$ Bad weather had a negative impact on yields and, in specific years, the yields fell below trend for corn, wheat and rice in particular. However, the harvested area for corn, for example, rose sharply in response to higher prices and by mid-decade there were record global crops for corn and oilseeds. These trends seem to indicate that supply was gradually responding to incentives and bad weather was neither generalized nor persistent. Between 2000 and 2007, for all grains, harvested area grew at 0.4 percent and yield grew at 1.3 percent per year, which equals a 1.7 percent annual growth in supply. ${ }^{9}$

On the demand side, consumption for food (including animal feed) of corn, wheat and rice was for the most part on trend. There were no surges in consumption on the part of China or India (or by developing countries in the aggregate) for corn, wheat or rice. The exception is oilseeds (soybeans in particular) for which the demand from China increased above trend. Demand for food consumption (including animal feed) for all grains grew at 1.7 percent per year from 2000 to $2007 .{ }^{10}$ Hence, excluding the demand for industrial use (biofuels), supply and demand grew at the same pace.

In contrast, after legislation on mandates, tariffs, and subsidies was passed in the EU and the US ${ }^{11}$, the demand for corn and vegetable oils for industrial use (biofuels) rose above trend and at an increasing rate. The use of corn for ethanol grew rapidly from 2004 to 2007. Feed use of maize, which accounts for 65 percent of global maize use, grew by only 1.5 percent per year from 2004 to 2007 while ethanol use grew by 36 percent per year and used 70 percent of the increase in global corn production. ${ }^{12}$ Industrial use of vegetable oils (which includes biodiesel) grew by 15 percent per annum from 2004 to 2007, compared with 4.2 percent per annum for food use (Table 2) It is estimated that about one-third of the increase in consumption from 2004 to 2007 was due to biodiesel. In Figure 2 we can observe how price increases of corn and soybeans accelerated after the demand for corn-based ethanol experienced its rapid increase. 
In quantitative terms, the contribution of biofuels to the rise in food commodities prices has been estimated or calculated using different time periods and prices, different coverage of food products, and different methodologies. ${ }^{13}$ The general conclusion that emerges from these exercises is that the contribution of the expansion of biofuels to observed price increases is quantitatively significant. Collins (2008) estimates that around 60 percent of the increase in maize prices from 2006 to 2008 may have been due to the increase in maize used in ethanol. Mitchell (2008) concludes that 70-75 percent of the increase in food commodities prices was due to biofuels and factors such as low grain stocks, large land use shifts, speculative activity and export bans. ${ }^{14}$ Using a general equilibrium model, Rosegrant, et al. (2008) estimates the impact of the acceleration in biofuel production on weighted cereal prices from 2000 to 2007 to be 30 percent in real terms. $^{15}$

How much of the increase in food commodities prices was caused by policyinduced increases in demand for biofuels as opposed to market forces such as higher gasoline prices (derived from higher oil prices)? According to McPhail and Babcock (2008) eliminating federal ${ }^{16}$ tax credits (for blending ethanol in gas) and tariffs_-and, to a much lesser extent, mandates - in the United States would reduce ethanol production by 18.6 percent and the price of corn would decline by 14.5 percent. While significant, this leaves a large portion of the increase unexplained. If gasoline prices are sufficiently high, the production of biofuels may be profitable even without the mandates, tax credits and the like. ${ }^{17}$ According to McPhail and Babcock (2008) ${ }^{18}$, even if government's support policies at the federal level are eliminated, if gas prices equal three dollars per gallon or higher, ethanol production would rise from the current levels of 6.5 billion gallons to 14 billion gallons and corn price would stay at four dollars a bushel ${ }^{19}$ (until recently prices were around seven dollars a bushel). ${ }^{20}$

Although markets were "stressed" before the expansion of biofuels production, in its absence, the price increases would have been more moderate, especially for corn. In particular, one would have expected the price increases to subside in 2004/05 when there were record global harvests in corn and oilseeds. Instead, price increases for corn accelerated. Between January 2002 and January 2004, for example, the monthly rate of growth for corn prices was one percent on average while between January 2005 and June 2007 the monthly rate of growth rose to 2.4 percent on average. With rising oil prices, consumers were willing to pay higher prices for biofuels and since global agricultural 
markets are highly interconnected, rising corn prices pushed other prices up through adjustments in behavior on the demand and supply side and arbitrage conditions. ${ }^{21}$

While the factors - if not the exact orders of magnitude-behind the reversal of the trend in food commodities prices since 2002 are more or less understood, a convincing explanation of the market dynamics of commodity prices from mid-2007 onwards remains elusive. The increase in prices of food commodities-along with other commoditiesaccelerated from mid-2007 up until mid-2008 when they began to fall at a fast pace: a third of the increase between 2002 and mid-2008 occurred during this twelve-month period (equivalent to 15 percent of the time). Understanding the market dynamics of commodity prices during this period remains elusive, yet there are three elements that may have contributed to these fluctuations: macroeconomic factors such as the depreciation of the dollar and lower interest rates in the United States, speculation and interventionist policies on the part of developing countries since mid-2007.

There is casual evidence that the price index of non-oil dollar commodities and the real value of the dollar have been inversely related. ${ }^{22}$ However, commodity prices rose in all major currencies. ${ }^{23}$ This is an indication that factors other than the depreciation of the dollar played a significant role. Since the acceleration in commodity price increases coincided with the onset of the sub-prime crisis in mid-2007, could the two events be related? Frankel (2008b) argues that the fact that commodity prices rose across the board calls for some macroeconomic explanation. For a while, the most popular macro explanation was rapid growth in the world economy. However, since mid-2007 (and until mid-2008) price rises accelerated even though the global economy was slowing down. ${ }^{24}$ According to Frankel (2006), Calvo (2008) and others, one of the explanations may be the Federal Reserve's decision to lower interest rates since mid-2007. Lower interest rates increase the demand for or reduce the supply of storable commodities through a variety of channels: by decreasing the incentive for pumping oil, mining gold, logging forests, culling cattle, etc. today rather than tomorrow; by increasing the desire to hold inventories; and, by encouraging investors (or speculators if you wish) to shift out of Treasury Bills and into other assets such as foreign currencies, emerging market stocks, other securities, and commodities—including food commodities. ${ }^{25}$

Frankel (2006) provides econometric evidence in support of the inverse relationship between commodity prices and real interest rates in the US dating back to the 1950s which is generally robust. Casual observation (Figure 3) suggests that the decisions to lower interest rates by the Federal Reserve in mid-2007 were followed by an 
acceleration in the price increases. However, after mid-2008 commodity prices have fallen in tandem with interest rates: between June 2008-when the IMF's Food Commodity Price Index peaked - and October 2008 prices fell by 27 percent. This casts some doubt on the theory that commodity prices increased due to inflationary expectations caused by the Fed's decision to lower interest rates. This is an area that deserves further research. ${ }^{26}$

The sharp decline in nominal commodity prices observed since mid-2008 is also consistent with the presence of a price bubble incentivized by lower interest rates in the United States. The importance of expansionary monetary policy or financial speculation as a cause of the acceleration of the commodity price increases has been dismissed because, if that were the case, one would have observed an increase in stocks of commodities-including food commodities. ${ }^{27}$ However, in the case of certain commodities such as oil or metals, stocks can be accumulated in "invisible" ways: by drilling or mining less. In the case of agricultural commodities, this option does not really exist because one cannot accumulate them by simply not harvesting a crop. But, as Calvo (2008) has argued, in the face of highly inelastic demand, the desired level of stocks may increase, but given the short run inelastic nature of supply, this may express itself through rising prices rather than higher stocks. ${ }^{28}$ Furthermore, it is naïve to think that stocks accumulated by sovereign governments are public knowledge in full. Finally, because of the recently created link between food commodities and fossil fuels through the biofuels nexus, part of the impact of lower interest rates on food commodities prices may be indirect (that is, there is no need to observe an accumulation of their inventories). ${ }^{29}$

The pattern of a sharp increase followed by a sharp fall in commodity prices is also consistent with changes in fundamentals. While investors expected the world economy to continue growing despite the US slowdown, they also expected the returns to non-US assets, including commodities, to rise. When in mid-2008 investors started to realize that the economic slowdown would be much more severe and global, the expectations went into the opposite direction and commodity prices began to fall.

Starting in the last quarter of 2007, governments of developing countries introduced administrative measures to ban or restrict exports and put bids on purchases of food commodities (Figure 4). These measures exacerbated the upward pressure of food commodities prices in international prices. ${ }^{30}$ The impact was particularly strong in the case of rice. ${ }^{31}$ In Figure 5 one can observe how acceleration in the price increases of rice coincided with some key countries introducing administrative measures that affected supply or demand. Likewise, in Africa, the domino effect on other prices did not wait; 
with rice and other imported cereals in short supply, the price of locally grown crops such as millet and sorghum rose. ${ }^{32}$ In an attempt to quantify the impact of administrative measures on world prices, Ivanic, et al. (2008) show that if developing countries try to offset a 50 percent increase in the world prices of rice, corn, wheat and soybeans by applying policy responses aimed at restoring individual countries' domestic prices, world market prices will rise by an additional 10 to 30 percentage points.

The fact that food commodities have become a profitable alternative for the production of fossil fuel energy substitutes has important implications. ${ }^{33}$ In contrast to food being used for consumption purposes whose income-elasticity is below unity (Engel's Law), the income elasticity for food commodities for industrial purposes could equal unity or more. ${ }^{34}$ This turn of events significantly alters the forces at play in food commodities markets and-depending on what happens to oil prices, biofuels subsidies and mandates and research on the agricultural frontier-food could become permanently more expensive in a nontrivial way. von Braun (2008a) argues that with the current growth path of biofuel production, oilseeds and corn prices would increase by 18 and 26 percent, respectively, by 2020. ${ }^{35}$ In contrast, the "business as usual”- that is, without biofuelsscenario mentioned above predicted an increase in food commodities prices of .26 percent per year or around five percent by 2020 .

In addition, the new link between the prices of food commodities and the prices of energy commodities makes the prices of the former much more sensitive to the business cycle and the vicissitudes of financial markets. While it is too early to test the latter using econometric techniques, the (de-trended) correlation between oil prices and corn prices since 2004, for example, is much higher than it was in previous decades: it rose from .36 during the period 1957-2003 to .65 during the period 2004-2008. ${ }^{36}$

\section{Rising Food Prices, Inflation and Poverty}

For developing countries, the impact of rising food commodities prices on inflation and poverty are of particular concern. Although domestic food prices have not risen as rapidly as international prices, ${ }^{37}$ IMF (2008a) estimates found that-between December 2007 and March 2008 - the median 12-month rate of food price inflation for a sample of 120 non-OECD countries rose from 10 percent to 12 percent, almost twice the median food price inflation rate of 2006 (Figure 6). Similarly, World Bank (2008b) finds that food inflation rose by around 20 percent in Bolivia, Azerbaijan, Bulgaria and Costa Rica and reached 30 percent in countries like Kyrgyz Republic and Sri Lanka in the same 
period. According to World Bank (2008c), headline inflation in developing countries rose by five percentage points between 2006 and 2008 and more than 30 developing countries featured double digit inflation rates. With the fall in commodity prices, headline inflation is declining in the second half of 2008.

The fact that rising food commodities prices cause inflationary pressures in poorer countries should not come as a surprise since food represents such a high percentage of their consumption basket. For example, in Nigeria, about 70 percent of income is spent on food, 75 percent in Vietnam, and 50 percent in Indonesia compared with 12 percent in the United States. However, inflationary pressures also affected middle-income countries with very diverse policy regimes: Chile, Venezuela, and several Eastern European and Central Asian countries. This is an area that deserves further research.

It is important to bear in mind that since the reported numbers refer to actual inflation rates, they do not necessarily reflect the inflationary pressures stemming from solely higher international food commodities prices. Actual inflation not only reflects inflationary dynamics but also the policy measures that governments take to respond to them. These policies can range from restrictive monetary and fiscal policies to interventions in specific markets (e.g., price controls, export bans, consumer subsidies and so on). That several monetary authorities increased interest rates by 25 basis points or more $^{38}$ despite its dampening effect on output is an indicator that governments faced important inflationary pressures. Another indicator is that, as mentioned in the previous section, many governments implemented trade, fiscal and administrative policies to contain the increase in domestic food prices. In the absence of these policies, inflation would have been even higher than what was observed.

What is the impact of higher food commodities prices on poverty? Since the poor include both net consumers and net sellers of food commodities, a change in their price in either direction will inevitably hurt some of the poor and benefit some of the poor simultaneously. Small poor farmers tend to benefit from higher food prices. However, the poor in urban areas and those in rural areas with little or no access to land are badly hurt when food prices increase. This contradictory impact of food prices on the poor has been known as the "food price dilemma."39 This dilemma has been the source of a futile debate regarding when the poor are better off: when food prices go up or when they go down. Policymakers should simply accept that if food prices rise (fall) poor net buyers (net sellers) will need help and poor net sellers (net buyers) will be better off. In either case, safety net programs will have to be expanded in coverage and size to compensate the 
group of the poor who are negatively affected. In addition, when food commodities prices increase, there is an opportunity to help poor net sellers translate this windfall into a more long-term improvement in living standards. With respect to the net impact on poverty (i.e., on summary measures such as the headcount ratio, the poverty gap ratio and the poverty gap ratio square), available evidence suggests that among the poorest households, the decline in living standards of net consumers caused by higher food prices outweighs the benefits accruing to net sellers in the majority of countries that have been analyzed so far. 40

As a general proposition, the impact on poverty generated by an increase in the price of food will depend on: i. the relative importance of different food commodities in the production set and consumption basket of different households and the difference between the two ${ }^{41}$; ii. the magnitude of the relative price change; iii. households' ability to substitute between food items; and, iv. the degree to which households are compensated for the price shocks by changes in their income (i.e., by the indirect effect on wages and employment originated by the price change). ${ }^{42}$ Evidence suggests that the poor spend between 50 and 70 percent of their income on food on average ${ }^{43}$; the proportion of poor people who are net buyers of food tends to dominate over the share of net sellers; the increase in domestic food price- though much lower than that observed for international prices-has been significant; although households do substitute more expensive for less expensive food, in the case of basic staples this substitution is limited; and the positive effects on wages take time.

Table 3 presents a summary of the estimates obtained by a series of recent studies which use different methods, poverty lines and assumptions about price increases, passthrough to domestic prices, substitution effects, and wage effects. Also, some include net sellers while others do not. The orders of magnitude of the estimated short-term impact of higher food prices on poverty are significant. Ivanic and Martin (2008a) show that about 105 million people in the least developed countries have been added to the world's poor since 2005 because of rising food prices. This is equivalent to about 10 percent of the people living on less than a dollar a day and, according to the authors, equivalent to approximately seven lost years of progress in poverty reduction. For Africa, Wodon et al. (2008) show that in twelve of the low-income countries an increase of 50 percent in food prices would lead to a 2.5 percentage point increase in the headcount ratio on average. The Asian Development Bank (2008) suggests that a 20 percent increase in food prices would raise the number of poor individuals by 5.65 and 14.67 million in Philippines and 
Pakistan, respectively. ${ }^{44} 45$ Even middle-income Latin America has not remained impervious: Robles et al. (2008) estimate that the increase in world food prices between January 2006 and March 2008 resulted in an increase of 4.3 percentage points in the headcount ratio or 21 million additional poor individuals. ${ }^{46}$ CEPAL (2008) - the UN Economic Commission for Latin America and the Caribbean- estimates that the ranks of the extremely poor and the moderately poor increased by 10 million each. ${ }^{47}$ So, despite all the differences in methodology and assumptions, these studies suggest that in the majority of countries, higher food commodities prices increase poverty. Although poverty increases considerably more in urban areas, with the exception of a few cases rural poverty rises as well. ${ }^{48}$

Research on specific countries re-enforces this result. Haq et al. (2008) find that food price increases in Pakistan might have increased urban poverty by 44.6 percent and rural poverty by 32.5 percent. Valero-Gil and Valero (2008) find that the spike in food prices during 2008 had a significant effect on poverty even after taking into account the positive effects of reduced taxes and tariffs and higher cash transfers to the poor. According to these authors, the incidence of consumption-based moderate poverty and extreme poverty increased from 25 to 33.5 percent and from 10.58 to 15.95 percent, respectively. Warr (2008) finds that higher food prices, especially staple grains, worsen poverty incidence in Thailand despite the presence of large numbers of poor farmers, many of whom benefit from higher prices.

\section{Policy Dilemmas caused by Rising Food Prices}

Given their impact on inflation and poverty, rising food commodities prices pose significant policy dilemmas to developing countries. The conventional wisdom among economists is that short-run problems associated with high prices of staple foods are best dealt with by appropriate macroeconomic instruments and targeted safety nets. However, as we shall see below, the policy dilemmas and challenges faced by governments in developing countries are substantial.

To fend off inflationary pressures, monetary authorities have two options: to accommodate the price increases as a one-time spike in the rate of inflation or to stick to the inflation target through tight monetary policy. Tight monetary policy has a dampening effect on economic activity. However, accommodation puts the hard-won credibility of central banks at risk; this must be weighed against the costs of tight monetary policy in terms of foregone output. Also, for countries in which wage and price indexation are 
common, it will be hard to prevent the initial increase in inflation from becoming entrenched. But given that fulfilling the inflation targets may mean that nonfood prices must fall in nominal terms, governments find it hard not to acquiesce to some degree of accommodation. ${ }^{49}$ Without accommodation (i.e., increase the money-supply), losses in economic activity are likely and this, in turn, would exacerbate the impact on poverty. In addition, the recessionary impact of tight monetary policy might reduce the fiscal resources available to compensate the poor through targeted safety nets.

In countries with large international reserves and sound fiscal and external stances, monetary authorities could use part of the reserves to encourage an appreciation of the currency which would immediately reduce the impact of higher international food commodities prices on domestic prices. However, relying on a macroeconomic price such as the exchange rate to deflect inflationary pressures has its costs. It creates disincentives to exporters and hurts import-competing sectors and, in more extreme cases, it can slow down growth.

The uncertainty regarding the causes and duration of rising food prices makes the dilemma even more complex. In the case where the former are the result of global inflationary pressures associated with US monetary policy, an appreciation of the currency-whenever feasible-is an appropriate response. However, as mentioned in section two, if food commodities price increases are subject to overshooting or are caused by a price bubble, then international prices are reflecting a transient distortion. Under such circumstances, using the heavy artillery of higher interest rates or an appreciation of the currency would result in "overkill." The problem is that in the midst of the process no one can be sure if the price increases are temporary or what portion of their acceleration reflects a distortion versus global inflation or changes in fundamentals.

Suppose now that governments accept the conventional wisdom and want to focus on protecting the poor from the impact of higher domestic food prices. Are developing countries ready? In particular, do safety net programs exist and can they be easily expanded? Do governments have the fiscal space to accommodate the additional resources needed to fund the safety net? Figure 7 presents the safety net programs available in low and middle-income countries by category: cash transfers, food for work, food ration/stamp and school feeding programs. Unfortunately, according to the available information, 19 (out of 49) low-income and 49 (out of 95) middle-income countries do not have safety net programs of any kind. 
Moreover, given the characteristic of the adverse shock-i.e., an increase in the price of a good that takes up a substantial portion of a poor person's budget - the most adequate safety net is to compensate the affected population for their loss in purchasing power in cash. ${ }^{50}$ Although cash transfer programs (conditional and unconditional) are increasingly more common, they are still not pervasive. Based on available information there are 16 (out of 49) low-income and 37 (out of 95) middle-income countries that have cash transfer programs. In the absence of cash transfer programs, countries could resort to school feeding programs. While they will not compensate the poor for the loss of purchasing power associated with higher food prices, school feeding programs can insulate (at least in part) children of poor households from suffering a cut in their food intake as a result of higher food prices. School feeding programs are a bit more common in low-income countries than cash transfer programs but still only 24 low-income countries have them.

In addition to the fact that there are many low- and middle-income countries which do not have safety net programs, those which exist may be too limited in coverage. In the case of Latin America and the Caribbean, for example, the coverage of cash transfer programs exceeds 25 percent of the population living in poverty in eight out of 26 countries: Brazil, Colombia, Chile, Ecuador, Honduras, Jamaica, Mexico and Panama. On a positive note, the two largest countries with the highest number of poor people in the region, Brazil and Mexico, have among the best functioning cash transfer programs in the world. ${ }^{51}$ The poorest countries in the region, however, either do not have programs or have them in a limited scale.

Furthermore, most of these programs do not have a mechanism to incorporate the "new" poor or increase the size of the benefits in the face of adverse shocks as part of their design. Some governments (Brazil and Mexico, for example) have increased the transfer to compensate for the loss in its purchasing power. However, the programs have not incorporated as beneficiaries those who became poor as a result of the food price increase. So far it is not clear how many of the countries with cash transfer programs have increased the amount of the transfer and incorporated the "new" poor into the program (or implemented a complementary program). ${ }^{52}$

In sum, the existing safety net systems in developing countries leave much to be desired. In too many countries they are either inexistent or small; and, even in countries in which cash transfer programs are large and effective in addressing chronic poverty, they are not designed to respond to shocks. This means that the majority of the poor who have 
been hurt or those who have become poor as a result of higher food prices were not being protected from the impact of higher food prices on their living standards. In cases in which these programs were expanded, this was done as an ad hoc measure implemented many months (or even years) after food price increases appeared on the scene. In addition, low-income countries in particular may not have the fiscal space to finance an expansion let alone launch new safety net programs. There is no available data in the public domain as to how many countries may be in such position. ${ }^{53}$

Confronted with lacking or inadequate safety nets, unpalatable macroeconomic choices, and uncertainty about the evolution of international food commodities prices, governments throughout the developing world implemented a series of administrative policies designed to insulate domestic food prices from their fluctuations in world markets. More than 80 developing countries for which data is available put in place at least one of the following: reduced import tariffs or other taxes, relaxed import restrictions, increased general consumer subsidies, raised export taxes, or introduced price controls, export restrictions or outright bans (Figure 4). The World Bank surveyed 118 countries and found that the most frequently adopted policies were food price controls, reduced food taxes, and consumption subsidies. ${ }^{54}$ Also, about a third of the countries implemented export restrictions. These measures were implemented even by countries with adequate safety net programs. ${ }^{55}$ This should not come as a surprise. Although beneficial to the poor, targeted safety nets do not contain inflationary pressures or prevent social discontent among low-income urban workers who are not poor enough to be included in the safety net system but are hurt by rising food prices.

With the exception of import-liberalizing, the rest of these measures has elicited quite a bit of criticism from multilateral institutions. The former are more acceptable to the mainstream because lowering trade barriers is considered to be efficiency-enhancing and consistent with a rules-based trading system. Heterodox measures such as export restrictions, general subsidies or price controls raise concern because they distort producers' and consumers' response to rising prices, defer and may worsen inflationary pressures, and can channel large amounts of scarce government resources to the non-poor. However, reducing tariffs also lowers government revenues which may not be desirable for countries facing fiscal imbalances. All of these administrative measures-including reducing import tariffs and other taxes on food items-exacerbate the upward pressure on commodity prices, hurting food commodity importers and, in the extreme, can be selfdefeating. However, an appreciation of the currency, a policy that has been recommended 
by some mainstream macroeconomists, could also exacerbate the upward pressure on international prices. ${ }^{56}$

The "best" policy option for individual countries will depend on two crucial factors: what the government's objective function is and where it enjoys the most degrees of freedom. If a government is concerned about containing inflation and at the same time preserving the credibility of the central bank, it may choose a policy path that is different from that of a government whose objective is to minimize the impact of higher food prices on the poor or to maintain social and political stability in the urban areas under limited fiscal and institutional resources. Countries with large international reserves, robust safety nets and fiscal space will choose a policy mix that is different from countries that have none of these. The fact that so many governments-from populist Argentina to conservative Mexico to pragmatic China, for example-chose to use administrative measures may be an indication that-despite their costs - they were viewed as the best option under the circumstances. ${ }^{57}$

\section{Concluding remarks}

Starting in 2002, international food commodities prices experienced large fluctuations. When prices were rising, developing countries faced significant policy dilemmas. Confronted with inflationary pressures, increasing poverty and social unrest, the vast majority of governments introduced beggar-thy-neighbor policies that reduced the welfare of particularly food-importing countries and undermined a rules-based trading system. This elicited substantial criticism from multilateral organizations and mainstream economists. Rather than trying to insulate domestic prices-it is argued-, governments should let prices adjust to reflect the change in international prices and use targeted safety nets to compensate the poor. However, as we saw above, safety nets in many developing countries are lacking or inadequate. If they are to be used in future episodes of rising food prices, they need to be put in place now. In particular, multilateral organizations should work with governments to implement cash transfer programs so that the poor can quickly and efficiently be compensated for the loss in purchasing power when food prices rise. It is essential that the new or existing programs are designed in such a way so that they can increase (decrease) the size of the transfer and the number of beneficiaries when the shock occurs (unwinds). That is, they should include an "insurance" component; this is not a feature which current programs have. ${ }^{58}$ In addition, governments should have 
mechanisms in place to ensure than when cash transfers need to be expanded, they will have the required fiscal space.

Even if adequate safety nets are in place, however, governments in developing countries would still need to cope with inflationary pressures and social discontent among urban households who are not poor enough to be included in the safety net programs but are hurt by higher food prices. Thus, the temptation to insulate domestic prices with beggar-thy-neighbor administrative measures will continue to exist. Moreover, such measures may not be inadequate if food price volatility in international markets is reflecting transient distortions resulting from global inflationary pressures or a food commodities price bubble. Among interventionist measures, however, some may be less problematic than others. The conventional wisdom in economics is that using taxes, subsidies and tariffs is better than price controls and export bans. But the availability of fiscal resources and political economy dynamics may change the ranking of policies.

As long as food commodities prices are subject to large fluctuations in international markets, it will be difficult to persuade developing countries not to implement measures that exacerbate the upward pressure on them. This will be particularly so in periods of high volatility, when price increases accelerate and governments in developing countries find it difficult to address the challenges to price stability, poverty reduction and social peace that soaring food prices cause. These welfare-decreasing measures could be avoided if international food commodities prices could be stabilized. The international community, through a multilateral organization such as the World Food Program, should explore how to create a public reserve of food staples to reduce price volatility. ${ }^{59}$ Recognizing that such an initiative would be costly and difficult to manage, these costs should be weighed against the benefits in terms of poverty reduction, nutrition and social stability that it would bring. In addition, public reserves could also help correct transient market distortions caused by hoarding, price bubbles or global inflationary pressures. ${ }^{\mathbf{6 0}}$ 
Table 1. Causes of Rising Food Commodities Prices: A Summary of the Literature

\begin{tabular}{|c|c|c|}
\hline & Demand & Supply \\
\hline $\begin{array}{l}\text { From January } 2002 \\
\text { until mid-2007 }\end{array}$ & $\begin{array}{l}\text { Excessively low prices in the past } \\
\text { Increase in food demand due to rising } \\
\text { living standards especially in China and } \\
\text { India } \\
\text { Expansive macroeconomic policies } \\
\text { resulting in too high global economic } \\
\text { growth in 2003-2007 } \\
\text { Depreciation of the dollar }\end{array}$ & $\begin{array}{l}\text { Excessively low prices in the past } \\
\text { Slowdown in output growth of } \\
\text { agricultural commodities } \\
\text { Bad weather and crop disease } \\
\text { Soaring energy and other agricultural } \\
\text { inputs prices } \\
\text { Diversion of food commodities to biofuels } \\
\text { production }\end{array}$ \\
\hline $\begin{array}{l}\text { From mid-2007 until } \\
\text { mid-2008 }\end{array}$ & $\begin{array}{l}\text { Reduction in US interest rates since mid- } \\
\qquad 2007 \\
\text { General subsidies, price controls, } \\
\text { reduction of import barriers and indirect } \\
\text { taxes on food items } \\
\text { Food hoarding and panic buying by } \\
\text { governments and individuals } \\
\text { Expansion of indexed funds and } \\
\text { speculation }\end{array}$ & $\begin{array}{c}\text { Export bans, export restrictions and } \\
\text { export taxes }\end{array}$ \\
\hline
\end{tabular}

Note: several sources; see section one in the text. 
Table 2. World Demand and Supply Summary: Corn, Wheat, Rice and Soybeans

\begin{tabular}{|c|c|c|c|c|}
\hline & CORN & RICE & WHEAT & OILSEEDS \\
\hline $\begin{array}{c}\text { HARVESTED AREA } \\
\text { (For all grains grew at } \\
0.4 \% \text { per year between } \\
2000-07^{*} \text { ) }\end{array}$ & $\begin{array}{l}\text { Increased } 15 \% \text { from } \\
2002 / 03 \text { to } 2007 / 08\end{array}$ & & $\begin{array}{l}\text { Declined by } 10.4 \% \\
\text { between } 1980 / 81 \text { to } \\
2006 / 07 \text { but recovering }\end{array}$ & $\begin{array}{l}\text { Declined after } 2005 / 06 \text {; land } \\
\text { used for corn (biofuels) in US, } \\
16 \% \text { decline in soybean area* }\end{array}$ \\
\hline $\begin{array}{c}\text { YIELD } \\
\text { (For all grains grew at } \\
1.3 \% \text { per year between } \\
2000-07^{*} \text { ) }\end{array}$ & $\begin{array}{l}\text { Below trend } 2005 / 06 \text { and } \\
2006 / 07 \text {, but on trend for } \\
\text { the rest }\end{array}$ & $\begin{array}{l}\text { Below trend } 2002 / 03 \\
2003 / 04,2004 / 05 \text { but on } \\
\text { trend for rest }\end{array}$ & $\begin{array}{l}\text { Below trend in } 2006 / 07 \\
\text { and } 2007 / 08 \text { but on } \\
\text { trend for rest** }\end{array}$ & Below trend in $2007 / 08$ \\
\hline $\begin{array}{l}\text { FOOD CONSUMPTION } \\
\text { (For all grains grew at } \\
1.7 \% \text { per year between } \\
2000-07^{*} \text { ) }\end{array}$ & $\begin{array}{c}\text { On trend (feed } \\
\text { consumption) } \\
\text { Grew at } 2.1 \% \text { per year in } \\
2000-07 \text { and } 2.6 \% \text { per year } \\
\text { in } 1995-00^{*}\end{array}$ & $\begin{array}{c}\text { On trend } \\
\text { Grew at } 1 \% \text { per year in } \\
2000-07 \text { and } 1.4 \% \text { per } \\
\text { year in } 1995-00^{*}\end{array}$ & $\begin{array}{c}\text { On trend } \\
\text { Grew at } 0.8 \% \text { per year } \\
\text { in } 2000-07 \text { and } 1.4 \% \\
\text { per year in } 1995-00^{*}\end{array}$ & $\begin{array}{l}\text { Above trend due to increased } \\
\text { demand in China** for animal } \\
\text { feed purposes and rise in human } \\
\text { consumption of fats }\end{array}$ \\
\hline $\begin{array}{l}\text { INDUSTRIAL USE } \\
\text { (biofuels) }^{\mathrm{a}}\end{array}$ & $\begin{array}{l}\frac{\text { Above trend and }}{\text { increasingly so since }} \\
\text { 04/05*b } \\
\text { Use of maize for ethanol } \\
\text { from } 2004 \text { to } 2007 \text { was } \\
70 \% \text { of the increase in } \\
\text { global maize production* } \\
\text { Feed use of maize grew by } \\
1.5 \% \text { per year from } 2004 \text { to } \\
2007 \text { while ethanol use } \\
\text { grew by } 36 \% \text { per year* }\end{array}$ & Not used for biofuels & Not used for biofuels & $\begin{array}{c}\text { Above trend for rapeseed and } \\
\text { palm since } 2000 / 01 \text { and soybeans } \\
\text { since } 2004 / 05^{\star \star} \\
7 \% \text { of global vegetable oil } \\
\text { supplies were used for biodiesel } \\
\text { production in } 2007 \text { and about } \\
\text { one-third of the increase in } \\
\text { consumption from } 2004 \text { to } 2007 \\
\text { was due to biodiesel* } \\
\text { Industrial uses of vegetable oils } \\
\text { grew by } 15 \% \text { per annum from } \\
2004 \text { to } 2007 \text {, compared with } \\
4.2 \% \text { per annum for food use } \\
\text { The share of industrial use of total } \\
\text { use rose from } 14.4 \% \text { in } 2004 \text { to } \\
18.7 \% \text { in } 2007^{*}\end{array}$ \\
\hline CHINA AND INDIA & $\begin{array}{l}\text { No consumption surge and } \\
\text { no significant role in } \\
\text { international markets }\end{array}$ & $\begin{array}{l}\text { No consumption surge; } \\
\text { China trades very little. } \\
\text { India was } 14 \% \text { of world } \\
\text { exports but fell to } 7-9 \% \\
\text { in } 2007 / 08 \text { and } 2008 / 09 . \\
\text { India's ban of rice } \\
\text { exports (Oct } 2007 \text { ) } \\
\text { probably had an effect } \\
\text { on world prices** }\end{array}$ & $\begin{array}{l}\text { No consumption surge } \\
\text { (in China, consumption } \\
\text { actually fell) and no } \\
\text { significant role in } \\
\text { international markets }\end{array}$ & $\begin{array}{c}\text { China's imports of palm oil and } \\
\text { soybean oil rose more sharply } \\
\text { since } 2002 / 03^{\star *}\end{array}$ \\
\hline $\begin{array}{c}\text { STOCKS-TO-USE RATIO } \\
\text { IN \% }\end{array}$ & $\begin{array}{c}\text { Lowest in } 2008 / 09 \text { since } \\
1973 / 74^{\star *}\end{array}$ & $\begin{array}{c}\text { Reached lows in } \\
2004 / 05 \text { and } \\
\text { subsequently leveled } \\
\text { off** }\end{array}$ & $\begin{array}{l}\text { Lowest in } 2007 / 08 \\
\text { since } 1960 / 61^{\star \star}\end{array}$ & $\begin{array}{l}\text { For soy and rapeseed oils in } \\
\text { lowest level since 1970s after } \\
2004 / 05 \text {. For palm oil, stocks-to- } \\
\text { use remain at levels of the } \\
1970 \text { s }^{\star \star}\end{array}$ \\
\hline
\end{tabular}

Source: Author's elaboration based on Mitchell (2008) (identified with “*”), Abbott et al. (2008) (identified with “**”) and own calculations based on USDA (2008) data.

a. Ethanol is produced from sugar crops, such as sugar cane or beets, or starchy crops such as maize. Biodiesel is produced from vegetable oils or animal fats.

b. Mitchell (2008) notes that "[t]he United States is the largest producer of ethanol from maize and is expected to use about 81 million tons for ethanol in the 2007/08 crop year. Canada, China and the European Union used roughly an additional 5 million tons of maize for ethanol in 2007, bringing the total use of maize for ethanol to 86 million tons, about $11 \%$ of global maize production... the U.S. accounts for about one-third of global maize production and two-thirds of global exports and used 25 percent of its production for ethanol in 2007/08." The author also states that "[t]he largest biodiesel producers were the European Union, the United States, Argentina, Australia, and Brazil, with a combined use of vegetable oils for biodiesel of about 8.6 million tons in 2007 compared with global vegetable oils production of 132 million tons." (Mitchell 2008, p.7) 
Table 3. Poverty Impacts of Recent Increases in Food Prices: A Summary of Available Studies

\begin{tabular}{|c|c|c|c|c|c|}
\hline & $\begin{array}{l}\text { Ivanic and Martin } \\
(2008 a)\end{array}$ & Wodon et al. (2008) & ADB (2008) & $\begin{array}{l}\text { Robles et al. } \\
(2008)\end{array}$ & CEPAL (2008) \\
\hline RESULTS & $\begin{array}{l}\text { Poverty increases in all } \\
\text { countries with the } \\
\text { exception of Peru. The } \\
2005-2008 \mathrm{Q} \text { price } \\
\text { increase scenario } \\
\text { increases national poverty } \\
\text { rates by } 4.5 \text { percentage } \\
\text { points on average } \\
\text { (calculating estimates for } \\
\text { all low income countries: } \\
\text { additional } 105 \text { million } \\
\text { people in poverty). }\end{array}$ & $\begin{array}{c}\text { Poverty increases. A } \\
50 \% \text { increase in prices } \\
\text { leads to an average } \\
\text { increase of the } \\
\text { headcount poverty of } 4.4 \\
\text { percentage points (or } 2.5 \\
\text { with producer impacts). } \\
\text { An average increase of } \\
3.5 \text { percentage points at } \\
\text { the national level in SSA } \\
\text { would lead to to around } \\
30 \text { million people in } \\
\text { poverty }\end{array}$ & $\begin{array}{c}\text { Poverty and } \\
\text { inequality increase in } \\
\text { the short-term. In the } \\
\text { medium-term it } \\
\text { depends. A } 20 \% \text { food } \\
\text { price increase in } \\
\text { Philippines and } \\
\text { Pakistan increases the } \\
\text { number of poor by } 5.65 \\
\text { and } 14.67 \text { million, } \\
\text { respectively. }\end{array}$ & $\begin{array}{l}\text { Poverty increases by } \\
4.3 \text { percentage points } \\
\text { or } 21 \text { million } \\
\text { additional poor } \\
\text { individuals (net } \\
\text { effect)*. For example, } \\
\text { total income poverty } \\
\text { increases by } 8 \\
\text { percentage points in } \\
\text { Guatemala (net effect } \\
\text { of intl. price increase), } \\
6.9 \text { in Mexico and } 6.5 \\
\text { in El Salvador }\end{array}$ & $\begin{array}{c}\text { Indigence } \\
\text { increases from } 12.7 \\
\text { (68.5 million people) } \\
\text { to } 14.7 \text { ( } 79.1 \text { million } \\
\text { people) with income } \\
\text { effects. Poverty } \\
\text { increases from } 35.1 \\
\text { (189.5 million } \\
\text { people) to } 37 \text { (199.6 } \\
\text { million) with income } \\
\text { effects }\end{array}$ \\
\hline COUNTRIES & $\begin{array}{c}\text { Bolivia, Cambodia, } \\
\text { Madagascar, Malawi, } \\
\text { Nicaragua, Pakistan, Peru, } \\
\text { Vietnam and Zambia }\end{array}$ & $\begin{array}{c}\text { Burkina Faso, DRC, } \\
\text { Ghana, Gabon, Guinea, } \\
\text { Liberia, Mali, Niger, } \\
\text { Nigeria, Senegal, Sierra } \\
\text { Leone, Togo }\end{array}$ & $\begin{array}{l}\text { Short-term Pakistan } \\
\text { and Philippines; } \\
\text { medium-term China } \\
\text { and Indonesia }\end{array}$ & $\begin{array}{l}\text { Nineteen countries in } \\
\text { LAC }\end{array}$ & $\begin{array}{l}\text { Estimates are for } \\
\text { Latin America and } \\
\text { the Caribbean as a } \\
\text { whole }\end{array}$ \\
\hline $\begin{array}{l}\text { INCLUDES NET } \\
\text { SELLERS }\end{array}$ & Yes & $\begin{array}{l}\text { Upper bound estimates } \\
\text { include net-buyers only; } \\
\text { lower bound estimates } \\
\text { assume net-sellers } \\
\text { receive price increase in } \\
\text { full }\end{array}$ & $\begin{array}{l}\text { Short-term estimates } \\
\text { includes buyers only; } \\
\text { medium-term CGE } \\
\text { should include effects } \\
\text { on net sellers }\end{array}$ & No & No \\
\hline WAGE EFFECTS & Yes & 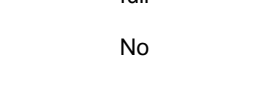 & Medium-term CGE yes & $\begin{array}{l}\text { Assumes agricultural } \\
\text { workers' incomes rise }\end{array}$ & $\begin{array}{l}\text { Assumes } \\
\text { everybody's income } \\
\text { rose } 5 \%\end{array}$ \\
\hline $\begin{array}{c}\text { SUBSTITUTION } \\
\text { EFFECT }\end{array}$ & No & No & Medium-term CGE yes & No & No \\
\hline $\begin{array}{c}\text { PRICE } \\
\text { INCREASE }\end{array}$ & $\begin{array}{l}\text { Three simulations: } 1.10 \% \\
\text { uniform increase/pass } \\
\text { through equal to } 1 ; 2 \text {. } \\
\text { 2005-07 actual FAO/pass } \\
\text { through .66; 3. 2005- } \\
\text { 2008Q1** }\end{array}$ & $\begin{array}{l}\text { Simulate price increases } \\
\text { of } 25 \% \text { and } 50 \% \text {; price } \\
\text { increases are the same } \\
\text { for all countries and all } \\
\text { food items }\end{array}$ & $\begin{array}{c}\text { Simulate food price } \\
\text { increases of } 10 \%, 20 \% \\
\text { and } 30 \%\end{array}$ & $\begin{array}{l}\text { Simulates the impact } \\
\text { of the IFS estimate of } \\
\text { price increases for six } \\
\text { commodities from Jan } \\
06 \text { to March } 08 \\
(68.1 \%) ; \text { full pass } \\
\text { through to domestic } \\
\text { prices. Also, simulates } \\
\text { price increases } \\
\text { estimated by central } \\
\text { banks }\end{array}$ & $\begin{array}{l}\text { Assumes a } 15 \% \\
\text { increase in food } \\
\text { prices }\end{array}$ \\
\hline POVERTY LINE & 1 dollar a day in PPP & 1 dollar a day & $\begin{array}{l}\text { Country-specific } \\
\text { poverty lines }\end{array}$ & $\begin{array}{l}\text { Country-specific } \\
\text { poverty lines }\end{array}$ & $\begin{array}{l}\text { Country-specific } \\
\text { poverty lines for } \\
\text { moderate and } \\
\text { extreme poverty }\end{array}$ \\
\hline $\begin{array}{l}\text { POVERTY } \\
\text { MEASURE }\end{array}$ & $\begin{array}{l}\text { Headcount ratio and } \\
\text { poverty gap ratio }\end{array}$ & Headcount ratio & $\begin{array}{l}\text { Change in absolute } \\
\text { number of poor; Gini } \\
\text { coefficient }\end{array}$ & $\begin{array}{l}\text { Headcount ratio and } \\
\text { poverty gap ratio }\end{array}$ & $\begin{array}{l}\text { Headcount ratio and } \\
\text { number of poor } \\
\text { individuals }\end{array}$ \\
\hline $\begin{array}{l}\text { ROBUSTNESS } \\
\text { CHECKS }\end{array}$ & $\begin{array}{c}\text { Poverty line; price } \\
\text { increases; labor market } \\
\text { segmentation }\end{array}$ & $\begin{array}{l}\text { Simulation of two levels } \\
\text { of price increases and } \\
\text { upper and lower bounds }\end{array}$ & $\begin{array}{l}\text { Simulation of three } \\
\text { levels of price } \\
\text { increases }\end{array}$ & $\begin{array}{l}\text { None that are } \\
\text { mentioned }\end{array}$ & $\begin{array}{l}\text { None that are } \\
\text { mentioned }\end{array}$ \\
\hline
\end{tabular}

* Own calculations based on the paper.

** For the 2005 to 2008.Q1 authors attempted to at what had actually happened to domestic prices. If a currency had appreciated against the USD, then the domestic price increase for these commodities was assumed to be smaller than the increase in $\$$ and we first made that adjustment. If other prices had increased, and we tracked this using inflation over the period, then the increase in food prices had to be compared relative to that increase in prices. So there were two adjustments: one for the exchange rate and one for increases in the general price level. 
Figure 1. Food Commodity Price Index (2005=100), January 2002-November 2008

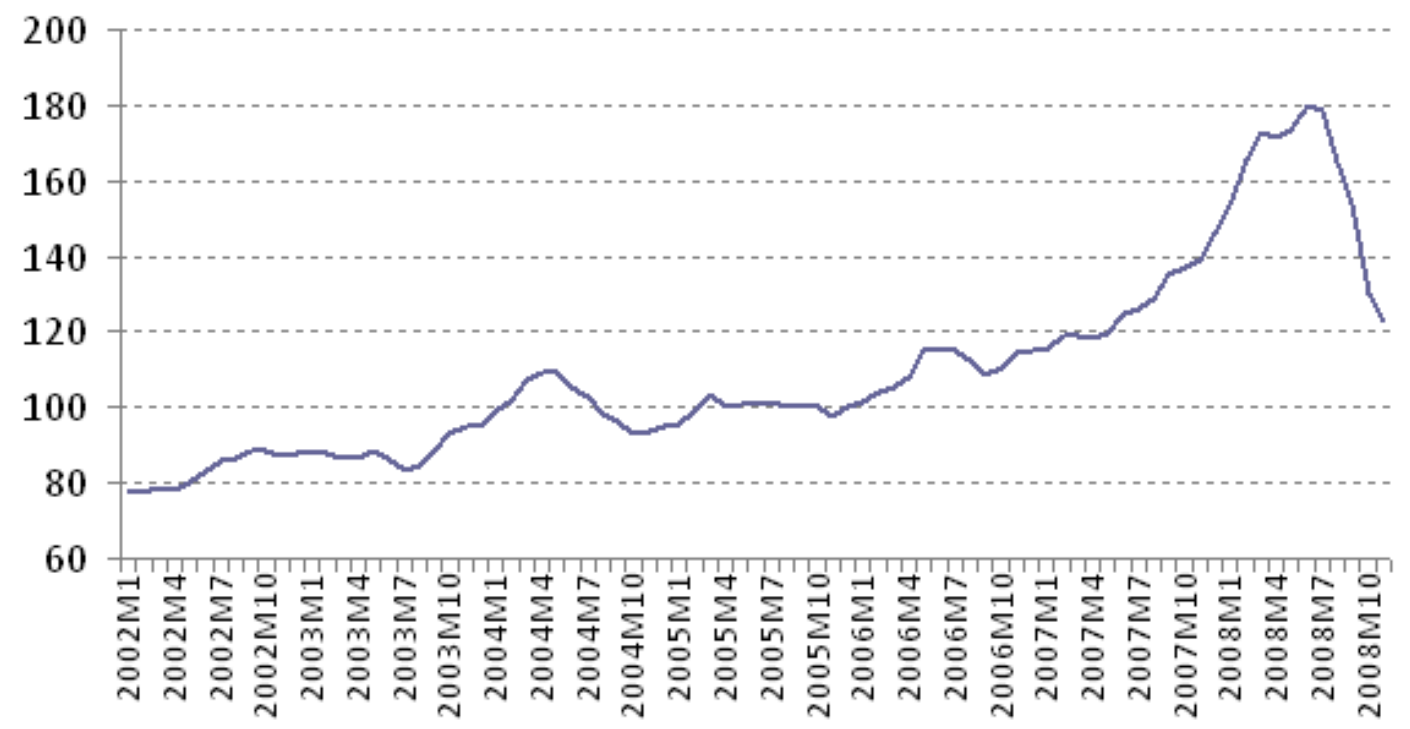

Source: IMF Primary Commodity Prices Database (2008c).

Figure 2. Corn and Soybeans Prices and U.S. Ethanol Production, 19952007

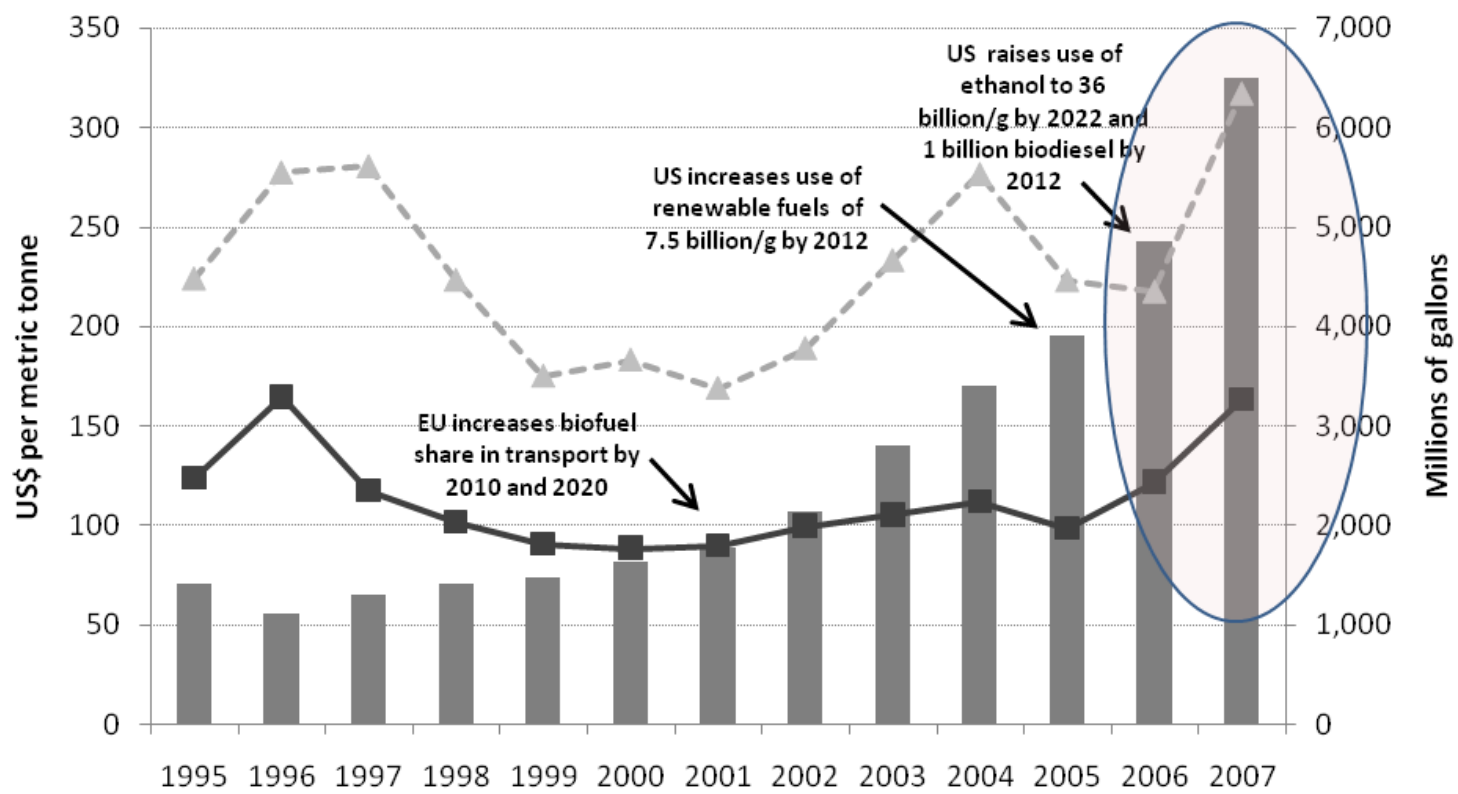

Source: Author's construction based on IMF Primary Commodity Prices Database (2008c) and Renewable Fuels Association. Notes: Ethanol production is for the United States. Prices refer to Maize (corn), U.S. No.2 Yellow, FOB Gulf of Mexico, U.S. price (average of daily quotations); Soybeans, U.S. soybeans, Chicago Soybean futures contract (first contract forward) No. 2 yellow and par (average of daily quotations). 
Figure 3. Monetary Policy in the U.S. and Food Commodities Prices, June 2006November 2008

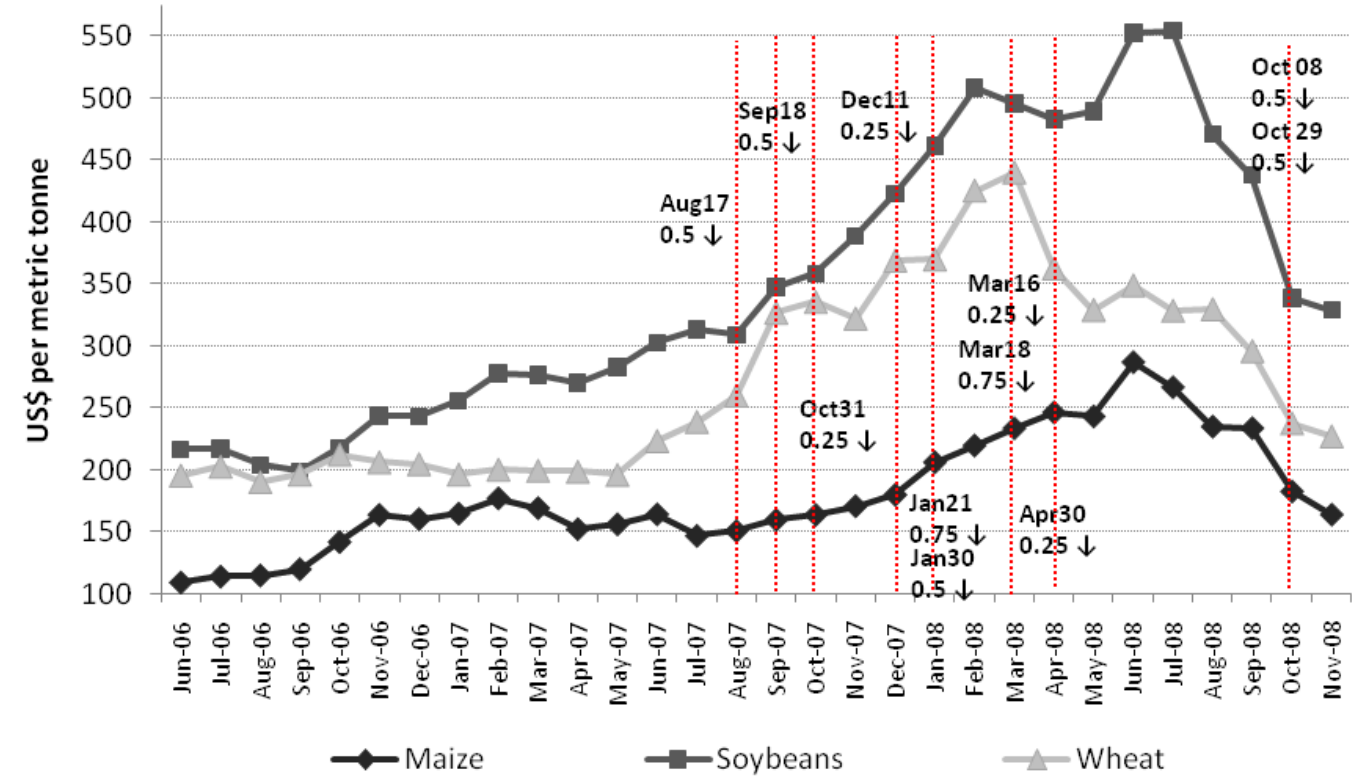

Source: Author's construction based on data from the IMF Primary Commodity Prices Database (2008c) and Federal Reserve Statistical Release (2008).

Notes: Vertical lines shows periods in which the Fed's primary credit rate was lowered as specified in the graph's text. The primary credit rate fell from 6.25 in June 2007 to 2.25 in June 2008 and further to 1.25 at the end of October (the discount rate is the interest rate charged by the Fed to commercial banks and other depository institutions on short-term loans (overnight)). The federal funds rate started to fall in August 2007 (after stability since mid-2006) from 5.02 to 2.01 by July 2008; at the end of October 2008 it was 1.00 ("the federal funds rate is the interest rate at which depository institutions lend balances at the Federal Reserve to other depository institutions overnight"; for more information visit www.federalreserve.gov). IMF prices for each product refer to: (i) Maize (corn), U.S. No.2 Yellow, FOB Gulf of Mexico, U.S. price (average of daily quotations); (ii) Soybeans, U.S. soybeans, Chicago Soybean futures contract (first contract forward) No. 2 yellow and par (average of daily quotations); (iii) Wheat, No.1 Hard Red Winter, ordinary protein, FOB Gulf of Mexico (average of daily quotations).

Figure 4. Policy Measures to Contain Price Increases and Number of Countries which Adopted Them

56

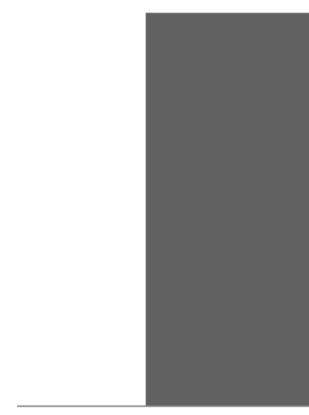

34

55

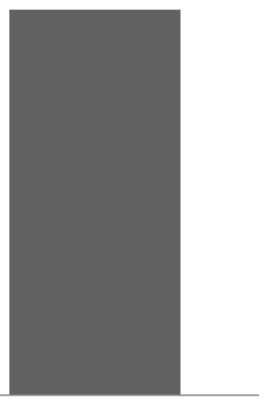

Price Controls/Consumer

Subsidies import restrictions

taxes

Source: Author's construction with information from the World Bank (2008d) and expanded with Trostle (2008), ADB (2008) and World Bank (2008e). 
Figure 5. Export Restrictions and the Price of Rice, June 2007-July 2008

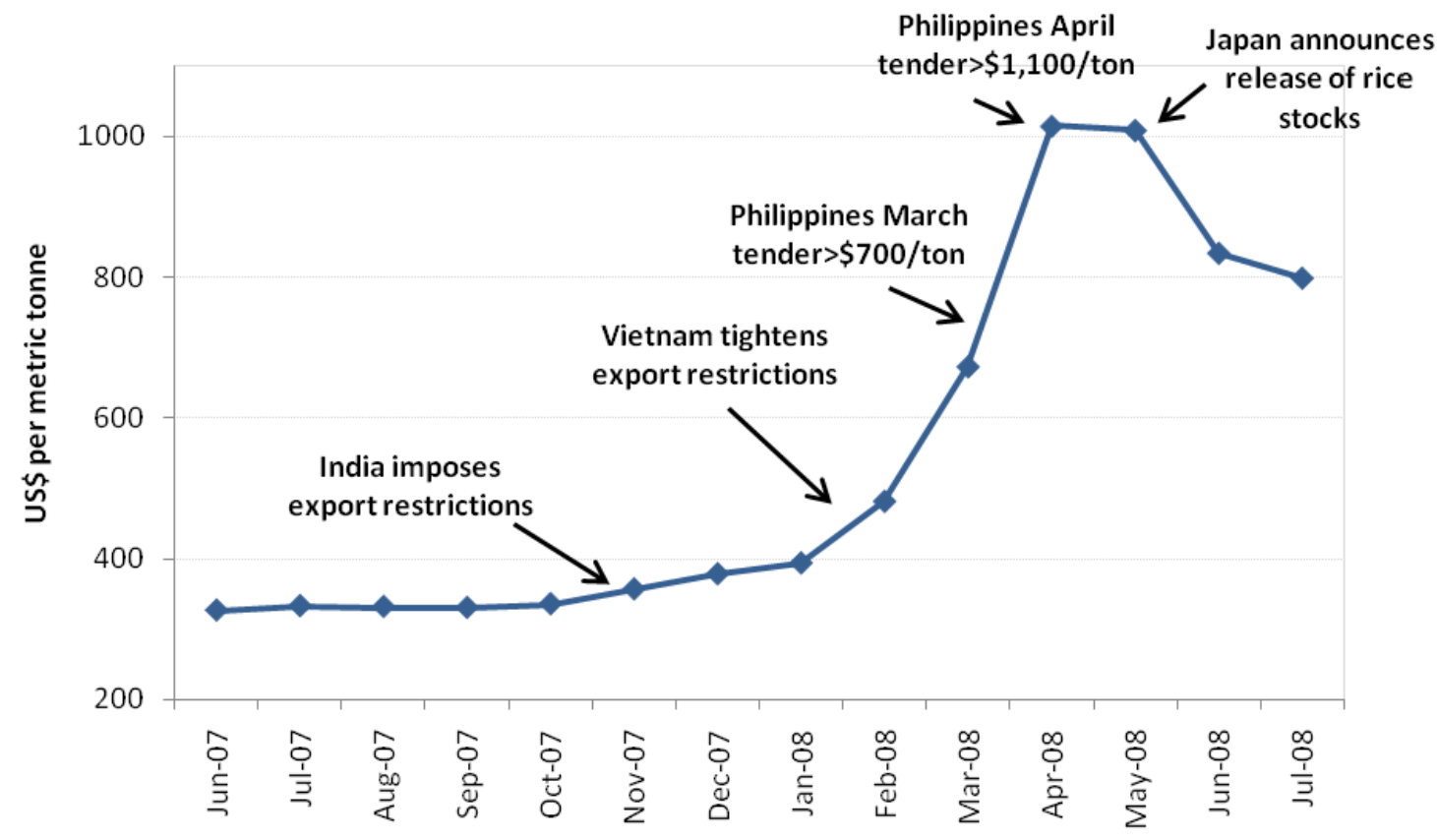

Source: IMF Primary Commodity Prices Database (2008c). Export policies from Slayton and Timmer (2008) and Timmer (2008). Based on a graph by Slayton and Timmer (2008).

Figure 6. Median Inflation in 120 non-OECD countries (y-o-y, in percent)

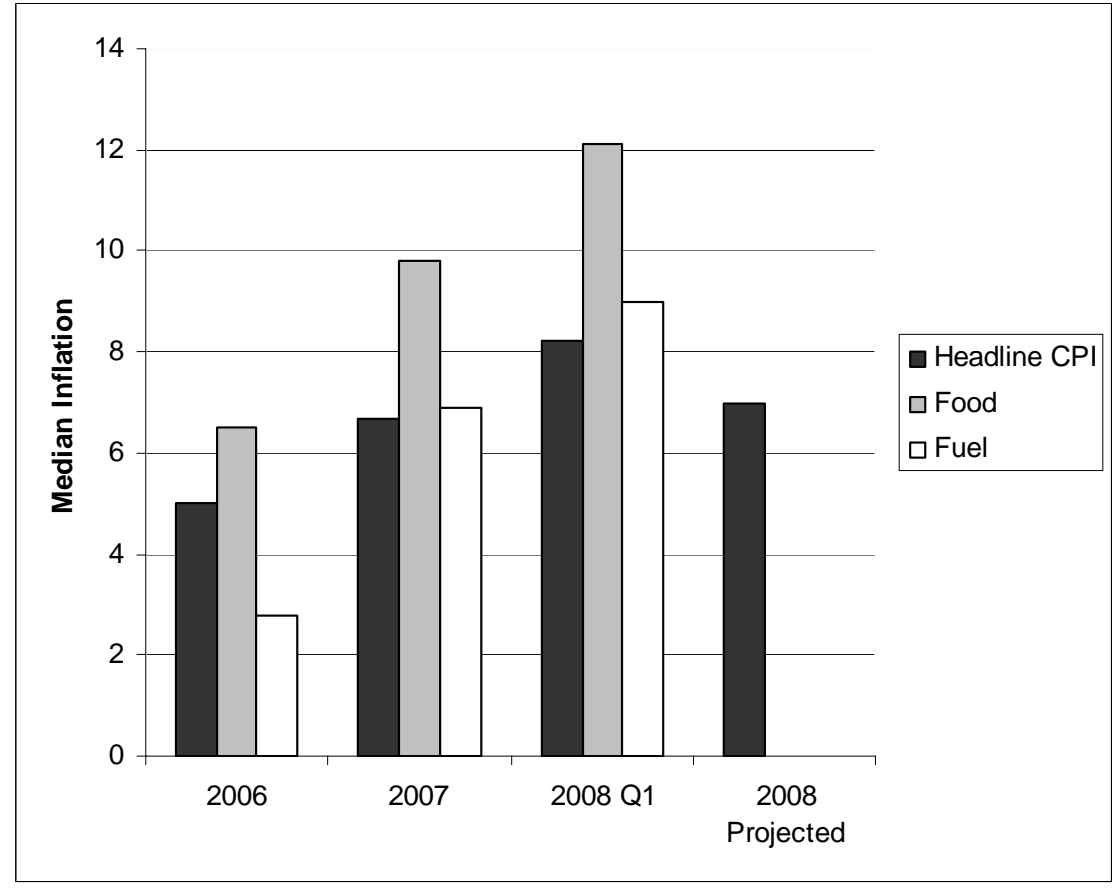

Source: Graph reproduced from the report IMF (2008a) page 18.

Note: Data was compiled by IMF staff and is not readily available. 
Figure 7. The Food Crisis: Safety Nets in Low- and Middle-Income Countries

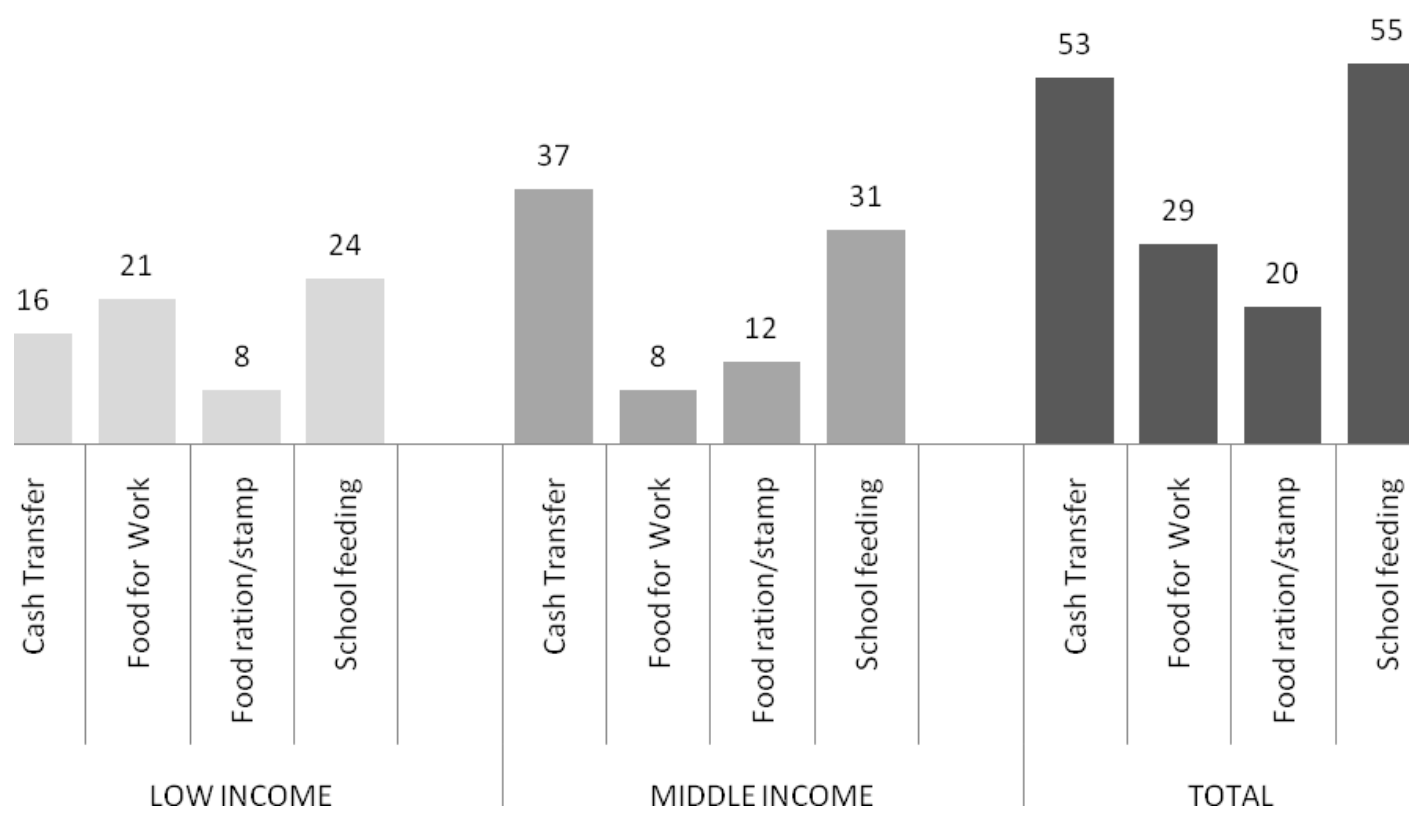

Source: Author's construction with information from the World Bank (2008d) and expanded with ADB (2008) and World Bank (2008e). Income classification data from the World Bank. The World Bank classifies 49 countries as low-income and 95 as middle-income; in the graph are those countries that implemented one or more programs (30 low income and 46 middle income countries). 


\section{References}

Abbott, Philip C.; Christopher Hurt and Wallace E. Tyner (2008) "What's Driving Food Prices”. Issue Report, Farm Foundation.

Asian Development Bank (2008) "Food Prices and Inflation in Developing Asia: Is Poverty Reduction Coming to an End?” Special Report, Asian Development Bank.

Aksoy, M. Ataman and Aylin Isik-Dikmelik (2008) "Are Low Food Prices Pro-Poor? Net Food Buyers and Sellers in Low-Income Countries.” Policy Research Working Paper 4642, The World Bank.

Calvo, Guillermo (2008) "Exploding commodity prices, lax monetary policy, and sovereign wealth funds.” VOX, June $20^{\text {th }}$. Available at: http://www.voxeu.org/index.php?q=node/1244.

Comision Economica para America Latina y el Caribe, CEPAL (2008) "Latin America and the Caribbean in the New International Economic Environment." Report of the Comision Economica para America Latina y el Caribe (Economic Commission for Latin America and the Caribbean.)

Collins, Keith (2008) "The Role of Biofuels and Other Factors in Increasing Farm and Food Prices: A Review of Recent Development with a Focus on Feed Grain Markets and Market Prospects." Supporting material for a review conducted by Kraft Foods Global, Inc. of the current situation in farm and food markets, June. Unpublished document.

Deaton, Angus (1989) "Rice Prices and Income Distribution in Thailand: A Non-Parametric Analysis.” The Economic Journal, Vol. 99, No. 395, Supplement: Conference Papers: 1-37.

De Janvry, Alain, Sadoulet, Elisabeth and Vakis, Renos (2008) "Protecting Vulnerable Children from Uninsured Risks: A New Role for Conditional Cash Transfer Programs?,” University of California at Berkeley and The World Bank, December, mimeo.

Dervis, Kemal (2008) “Q \& A with Kemal Dervis, head of the UN Development Program.” In “Managing Globalization” (Blog) by Daniel Altman, August 13th, International Herald Tribune.

Elliott, Kimberly (2008) "Biofuels and the Food Price Crisis: A Survey of the Issues.” Working Paper Number 151, Center for Global Development.

Federal Reserve Statistical Release (2008) "Selected Interest Rates, Historical Data." http://www.federalreserve.gov/releases/h15/data.htm

Fleshman, Michael (2008) "Africa struggles with soaring food prices. From emergency reactions to farming investments." Africa Renewal, Vol.22 \#2 (July): 12. Available at: http://www0.un.org/ecosocdev/geninfo/afrec/vol22no2/222-africa-struggles-with-food-prices.html.

Frankel, Jeffrey (2006) “The Effect of Monetary Policy on Real Commodity Prices.” Working Paper 12713, National Bureau of Economic Research.

Frankel, Jeffrey (2008a) “Fed Modesty Regarding Its Role in High Commodity Prices.” Jeff Frankel's Weblog, May $21^{\text {st }}$. Available at:

http://content.ksg.harvard.edu/blog/jeff_frankels_weblog/category/commodities/.

Frankel, Jeffrey (2008b) “An Explanation for Soaring Commodity Prices.” VOX, March 25th. Available at: http://www.voxeu.org/index.php?q=node/1002. 
Frankel, Jeffrey (2008c) "Monetary policy and commodity prices.” VOX, March 29th. Available at: http://www.voxeu.org/index.php?q=node/1178.

Gately, Dermot and Hillard G. Huntington (2001) "The Asymmetric Effects of Changes in Price and Income on Energy and Oil Demand.” Economics Research Report, C.V. Starr Center for Applied Economics, New York University.

Haq, Zahoor ul; Nazli, Hina; Meilke, Karl (2008) "Implications of high food prices for poverty in Pakistan,” Agricultural Economics, Volume 39, Supplement 1, Special issue on the world food crisis, pp. 477-484(8).

International Food Policy Research Institute (2003) “A Level Playing Field for Poor Farmers.” Ifpri Forum, March.

International Monetary Fund (2008a) "Food and Fuel Prices-Recent Developments, Macroeconomic Impact, and Policy Responses." Prepared by the Fiscal Affairs, Policy Development and Review, and Research Departments. International Monetary Fund Report.

International Monetary Fund (IMF) (2008b) "International Financial Statistics (IFS) Online.” http://www.imfstatistics.org/imf/logon.aspx ${ }^{61}$

International Monetary Fund (IMF) (2008c) "Primary Commodity Prices Database."

http://www.imf.org/external/np/res/commod/index.asp

International Monetary Fund (IMF) World Economic Outlook, July 2007 and January 2008.

Ivanic, Maros and Will Martin (2008a) "Implications of higher global food prices for poverty in low-income countries.” Policy Research Working Paper Series 4594, The World Bank.

Ivanic, Maros and Will Martin (2008b) "The Food Price Crisis, Poverty and Agricultural Trade Policy,” mimeo, World Bank, October.

Ivanic , Marcos, Will Martin, Aaditya Mattoo and Arvind Subramanian (2008) "Likely Consequences of Attempted Price Insulation in the Global Agricultural Markets,” mimeo, World Bank.

Krugman, Paul (2008) “Commodities and speculation: metallic (and other) evidence.” New York Times’ Blog, April 20"th.

Lin, Justin (2008) Remarks presented at "Preparing For The Next Global Food Price Crisis," Center For Global Development, Washington, Dc, October 6.

Lipsky, John (2008) “Commodity Prices and Global Inflation.” Remarks at the Council on Foreign Relations, New York City, May 8.

Lustig, Nora (1986) “Food Subsidy Programs in Mexico.” Working Paper No. 3, International Food Policy Research Institute, Washington, D.C., January.

Lustig, Nora (2008) "Thought for Food: the Causes and Consequences of Rising Food Prices,” Working Paper 155, Center for Global Development, Washington, DC.

McPhail, Lihong Lu and Bruce A. Babcock (2008) "Short-Run Price and Welfare Impacts of Federal Ethanol Policies.” Working Paper 08-WP 468, Center for Agricultural and Rural Development, Iowa State University. 
Mellor, J. W. (1978) "Food Price Policy and Income Distribution in Low-Income Countries.” Economic Development and Cultural Change, 1: 1-26.

Mitchell, Donald (2008) “A Note on Rising Food Prices”. Policy Research Working Paper 4682. The World Bank.

Mundell, Robert (2002) "Commodity Prices, Exchange Rates and the International Monetary System.” Consultation on Agricultural Commodity Price Problems, Food and Agriculture Organization.

Naylor, Rosamond L. and Walter P. Falcon (2008) “A New Variety of Food Crisis.” Unpublished document.

Organization for Economic Co-operation and Development (2008) "Economic Assessment of Biofuel Support Policies.” Report of the Directorate for Trade and Agriculture, Organization for Economic Co-operation and Development.

Pinstrup-Andersen (1987) “Food Prices and the Poor.” In J. Price Gittinger, Joanne Leslie and Caroline Joisington "Food Policy. Integrating Supply, Distribution and Consumption”, Johns Hopkins University Press.

Ravallion, M., and D. van de Walle (1991) "The impact on poverty of food pricing reforms: A welfare analysis for Indonesia.” Journal of Policy Modeling 13 (2): 281-299.

Ravallion, Martin (1990) "Rural Welfare Effects of Food Price Changes Under Induced Wage Responses: Theory and Evidence for Bangladesh.” Oxford Economic Papers. Oxford: Jul 1990. Vol. 42, Iss. 3: 574 (12 pages).

Renewable Fuels Association (2008) "Ethanol Industry Statistics." http://www.ethanolrfa.org/industry/statistics/

Revenga, Ana (2008) “Rising food prices: Policy options and World Bank response,” World Bank, mimeo. http://www.google.com/search?q=revenga+food+prices\&ie=utf-8\&oe=utf8\&aq=t\&rls=org.mozilla:en-US:official\&client=firefox-a

Robles, Marcos; Jose Cuesta; Suzanne Duryea; Ted Enamorado; Alberto Gonzales, and Victoria Rodríguez (2008) "Rising Food Prices and Poverty in Latin America: Effects of the 2006-2008 Price Surge.” Inter-American Development Bank.

Rosegrant, Mark W.; Tingju Zhu; Siwa Msangi; Timothy Sulser (2008) "Biofuels and Cereal Prices: How Much has Growth in Biofuel Production Influenced World Cereal Prices?” International Food Policy Research Institute. Unpublished document.

Slayton, Tom and Peter Timmer (2008) "Japan, China and Thailand Can Solve the Rice Crisis-but US leadership is needed." CGD Notes, Center for Global Development.

Timmer, C.; W. Falcon, and S. Pearson (1983) “Food Policy Analysis.” Johns Hopkins University Press, 1983: 1- 301.

Timmer, Peter (2008) “The causes of high food prices.” Unpublished document.

Trairatvorakul (1984) "The Effects on Income Distribution and Nutrition of Alternative Rice Price Policies in Thailand.” Research Report 46, International Food Policy Research Institute, November 1984. 
Trostle, Ronald (2008) "Global Agricultural Supply and Demand: Factors Contributing to the Recent Increase in Food Commodity Prices." WRS-0801, United States Department of Agriculture, Economic Research Service.

United States Department of Agriculture (USDA) (2008) "Feed Grains Database." http://www.ers.usda.gov/Data/feedgrains/FeedGrainsQueriable.aspx

United States Department of Agriculture (USDA) (2008a) "Production, Supply and Distribution (PSD) online database.”

http://www.fas.usda.gov/psdonline/

Valero-Gil, Jorge N. and Magali Valero (2008) "The effects of rising food prices on poverty in Mexico,” Agricultural Economics, Volume 39, Supplement 1, Special issue on the world food crisis pp. 485-496(12).

von Braun, Joachim (2008a) "Biofuels, International Food Prices, and the Poor." International Food Policy Research Institute, Testimony to the United States Senate Committee on Energy and Natural Resources, June $12^{\text {th }}$.

Warr, Peter (2008) "World food prices and poverty incidence in a food exporting country: a multihousehold general equilibrium analysis for Thailand” Agricultural Economics, Volume 39, Supplement 1, Special issue on the world food crisis, pp. 525-537(13).

Wodon, Quentin et al. (2008) "The Food Price Crisis in Africa: Impact On Poverty And Policy Responses.” World Bank (mimeo).

Wodon, Q. and Zaman, H. (2008), 'Poverty impact of higher food prices in sub-Saharan Africa and policy responses’ Mimeo, World Bank.

World Bank (2007) “World Development Report 2008: Agriculture for Development.” World Development Report, The World Bank.

World Bank (2008b) "Addressing the Food Crisis: The Need for Rapid and Coordinated Action.” Background Paper for the G8 Ministers of Finance Meeting. Washington, DC: World Bank.

World Bank (2008c) Global Economic Prospects 2009. Commodities at a Crossroads, Washington, DC.

World Bank (2008d) "Double Jeopardy: Responding to High Food and Fuel Prices.” G8 Hokkaido-Toyako Summit. Washington, DC: World Bank.

World Bank (2008e) "Food Price Inflation and its Effects on Latin America and the Caribbean." Washington, DC: World Bank. 
${ }^{1}$ From January until September 2008.

${ }^{2}$ World Bank (2008b, 2008c).

${ }^{3}$ This option, however, benefits net-sellers including those who are poor.

${ }^{4}$ The so-called "Dutch Disease."

${ }^{5}$ Given the methodological difficulties involved, however, an attempt to estimate the exact contribution of each of these factors using econometrics or a comprehensive simulation model would be an impossible task.

${ }^{6}$ World Bank (2007), p. 50. Low prices were also the consequence of agricultural support policies in the European Union and the United States (IFPRI, 2003).

${ }^{7}$ World Bank (2007), p. 62.

${ }^{8}$ Timmer (2008) estimates that lower prices in the previous decade explain around 53 percent of the increase. On the harvested area and yield by crop see, for example, Abbott et al. (2008). Also, see Naylor and Falcon (2008).

${ }^{9}$ Mitchell (2008).

${ }^{10}$ Ibid.

${ }^{11}$ Legislation was passed in 2005 and implemented in 2006.

${ }^{12}$ Ibid.

${ }^{13}$ For example, computable general equilibrium models (Rosegrant et al., 2008) or partial equilibrium analysis (Collins, 2008) or estimated as an accounting residual (Mitchell, 2008).

${ }^{14}$ Ibid., p. 16.

${ }^{15}$ Also, in the short-run, the IMF estimated that the increased demand for biofuels accounted for 70 percent of the increase in maize prices and 40 percent of the increase in soybean prices (Lipsky, May 8, 2008). A recent OECD report (OECD, 2008) calculates that "current biofuel support measures are estimated to increase average wheat, maize and vegetable oil prices by about $5 \%, 7 \%$ and $19 \%$, respectively, in the medium term" (p.9).

${ }^{16}$ In addition to policies at the federal level, there are mandates and other policies at the state level which also affect ethanol and biodiesel production. (Elliott, 2008)

${ }^{17}$ In fact, as Elliott (2008) shows that the mandated levels required by the Energy Policy Act of 2005 in the United States were apparently non-binding.

${ }^{18} \mathrm{http} / / /$ www.econ.iastate.edu/research/webpapers/paper_12943.pdf.

${ }^{19}$ A bushel is equal to 56 pounds.

${ }^{20}$ This is not proof that the same increase in biofuels production would have existed without government support. It is still possible that without the tax credits or protection from imports, the production of biofuels at those same prices would have been lower. For more on this, see Naylor and Falcon (2008).

${ }^{21}$ See Naylor and Falcon (2008) for an account of the interaction between ethanol and corn, soybean and wheat price.

${ }^{22}$ According to Mundell (2002): “[A] casual reading of the statistics suggests that this relationship is quite close. Thus the index of non-oil dollar commodities tripled in the 1970s when the dollar was depreciating sharply relative to the SDR; it then fell by more than 20 per cent from 1980 to 1986 when the dollar was soaring; then it rose by 50 per cent from 1986 to 1995 when the dollar was again depreciating; and it has fallen by 30 per cent since 1995 when the dollar has been appreciating. There is therefore a very pronounced association of the cycle of the dollar against other major currencies (as measured by the SDR) with the cycle of dollar commodity prices."

${ }^{23}$ See Lustig (2008), Figures 9 and 10.

${ }^{24}$ The IMF reduced predicted growth rates for the world in 2008 from 5.2 percent in July 2007 to 4.1 percent in January 2008 (IMF World Economic Outlook Updates for July 2007 and January 2008). These numbers have changed in subsequent versions.

${ }^{25}$ See Frankel (2008a, b, and c) for his comments and exchange with other economists on this issue.

${ }^{26}$ Another factor which has been mentioned to explain the acceleration in commodity price increases since mid-2007 is speculation in financial markets due to the rise in the participation of index funds. So far, the evidence for this is very limited. World Bank (2008c)

${ }^{27}$ See, for example, Krugman (2008).

${ }^{28}$ Note that government interventions to restrict exports and expand subsidies contributed to the inelasticity of supply and demand.

${ }^{29}$ However, correlation is not proof of causality. The spike in prices could also be explained by the nonlinearities present in tight commodity markets which were subject to additional shocks such as the administrative decisions mentioned above (export bans, export taxes, etc.). And the recent fall could be explained by the expected downward pressure on prices resulting from a slowdown in global growth. In addition, the inverse relation between commodity prices and interest rates does not always hold empirically.

${ }^{30}$ See Ivanic , Martin, Mattoo and Subramanian (2008).

31 See Slayton and Timmer (2008), Naylor and Falcon (2008).

${ }^{32}$ Naylor and Falcon (2008) and the article by Fleshman (2008).

${ }^{33}$ By this we mean the use of food commodities to produce energy for cars and machines.

${ }^{34}$ The long-run income elasticity of energy and oil has been estimated at approximately 1.0 for the non-OECD countries (Gately and Huntington, 2001).

35 According to OECD (2008) estimates, a full implementation of the recently enacted US Energy Independence and Security Act and the currently proposed new EU Directive for Renewable Energy, close to $20 \%$ of global vegetable oil production and more than $13 \%$ of world coarse grain output could shift to biofuels production”. The EU directives were revised so their impact needs to be re-estimated. 
${ }^{36}$ Correlations were estimated using the de-trended monthly series of commodity prices published by the International Monetary Fund in the International Financial Statistics (2008b)

${ }^{37}$ The World Bank (2008c) finds that among 73 countries for which monthly consumer price index and household survey data are available, the majority had real food price increases of 12 percent or less.

${ }^{38}$ This happened in Brazil, Indonesia, Mexico, the Philippines, South Africa, and Thailand. (World Bank, 2008c)

${ }^{39}$ Timmer, Falcon and Pearson (1983), Chapter 1. This dilemma has been analyzed empirically for a number of countries. See, for example, Deaton (1989); Lustig (1986); Mellor (1978); Pinstrup-Andersen (1987); Ravallion and van de Walle (1991); Ravallion (1990); Trairatvorakul (1984).

${ }^{40}$ Aksoy and Isik-Dikmelik (2008), for example, argue that many of the poor are net sellers of food commodities so that higher prices is a benefit to them. While this is true, the studies that estimate the full impact (i.e., on net sellers and net buyers), find that higher food prices result in an increase in the headcount and poverty gap ratios in the overwhelming majority of cases (Ivanic and Martin, 2008a; Wodon et al., 2008; Robles et al., 2008; CEPAL, 2008).

${ }^{41}$ For poor farmers, the difference is often positive indicating that they benefit from a price increase. In contrast, poor urban households or landless agricultural workers are net consumers of food commodities and get hurt by an increase in their price.

${ }^{42}$ To estimate the latter, one must be able to estimate the spillover effects; this has been done using multi-sectoral and full-fledged computable general equilibrium models. Some CGEs are Walrasian, that is, all markets clear via prices and there is no unemployment. Others are more heterodox: they assume flexible prices in some markets but in others prices are determined as a mark-up above costs and total employment is endogenously determined by the level of aggregate demand.

${ }^{43}$ World Bank (2008c), p. 119.

${ }^{44}$ For a more extreme scenario of 30\% increase in food prices, the number of poor people increases by 8.85 and 21.96 million in Philippines and Pakistan, respectively.

${ }^{45}$ It is important to point out that these estimates on the poverty impact of higher food prices do not take into account the positive effect that higher food commodities prices have had on economic growth in net exporting countries. In addition to their impact on macroeconomic performance and poverty, rising food prices were a source of social unrest and created severe budgetary difficulties for food aid programs and made planning for food relief excruciatingly difficult.

${ }^{46}$ Regional numbers for Latin America are based on Robles et al. (2008) country-by-country estimations for net increase in poverty.

${ }^{47}$ CEPAL (2008) assumes that incomes rose at the same pace as the consumer price index.

${ }^{48}$ World Bank (2008c), p. 116.

${ }^{49}$ Even the IMF (2008a) has recognized that inflation targets might have to be missed in order to avoid an excessive reduction in output or output growth. Also, see Dervis (2008).

${ }^{50}$ Since the problem is loss in purchasing power and not in employment, expanding food-for-work or cash-for-work programs is not the most adequate response and could potentially introduce distortions in the allocation of labor supply on the part of poor households. However, increasing the wage paid in cash-for-work programs is an adequate response.

${ }^{51}$ Bolsa Familia in Brazil and Oportunidades in Mexico.

52 There is evidence that Ethiopia increased the wage rate in its cash-for-work program and that other poor countries have relied on food-for-work, food distribution and school feeding programs to transfer resources to the poor. For a discussion on this see Revenga (2008).

${ }^{53}$ IMF (2008a) indicates which countries need the IMF because of balance of payments vulnerability but there is no indication how many countries may need its assistance to expand or implement a safety net.

${ }^{54}$ See, for example, Revenga (2008), Ivanic and Martin (2008b) and Wodon and Zaman (2008).

${ }^{55}$ Mexico, for example, increased the size of the transfers in its cash transfer program but it also lowered tariffs on agricultural goods and inputs, implemented some forms of "soft" price controls and increased general subsidies on some food staples.

${ }^{56}$ Even safety nets to the poor could put upward pressure on international prices. However, the increase in demand for food resulting from an expansion of safety nets is bound to be lower than, for instance, general consumption subsidies or price controls. In addition, safety nets do not lower the price to the supplier allowing for a positive response on their part to take place.

57 The choice of which specific administrative measures to use should be based on "common sense" criteria. For example, governments should choose those price policy interventions which are more easily reversed (that is, they do not become hijacked by special interest groups), least distortionary, least regressive, more consistent with a rules-based trading system, simple to implement from an administrative point of view and do not cause unsustainable fiscal imbalances. In this process governments are likely to face complex and difficult to quantify trade-offs.

${ }^{58}$ For a discussion on how the cash transfer programs can be adapted to incorporate an "insurance" component, see De Janvry et al. (2008).

${ }^{59}$ See the proposal made by Lin (2008), for example.

${ }^{60}$ Dealing with secular upward pressures on international food commodities prices caused by the surge in the production of biofuels will require a different approach. Certainly subsidies for biofuels production in advanced countries should be eliminated. However, if the price of gasoline gets to be high enough, it will be profitable to produce them without subsidies. In this case, countries may have to consider a tax on biofuels production. Otherwise, it will be increasingly difficult to protect the poor in developing countries from the impact of rising food prices.

${ }^{61}$ Please note that this database requires login information, thus the hyperlink to the data cannot be provided precisely. 